\title{
The Importance of Work Satisfaction in Mediating The Relationship Between Superleader and Employee Performance
}

\author{
Yuntawati Fristin a *, Umar Nimran ${ }^{\text {b }}$, M. Al Musadieq ${ }^{\text {c }}$, Hamidah Nayati Utami ${ }^{\text {d }}$ \\ ${ }^{a}$ Merdeka University, Malang, East Java, Indonesia \\ ${ }^{a}$ Brawijaya University, Malang, East Java, Indonesia
}

\section{INFORMASI ARTIKEL}

\section{Article history:}

Data submission : 25 September 2018

$1^{\text {st }}$ revision: 10 October 2018

Accepted: 19 November 2018

Available online: 30 December 2018

Keywords: superleader, work satisfaction, work performance

\begin{abstract}
This research is aiming at analysing and explaining the effect of Superleader on Work Satisfaction; the effect of Superleader on work performance; and the effect of Work Satisfaction on Work Performance. The number of samples used in this research is 240 people. The data is analysed by using Generalized Structured Component Analysis (GSCA). The result shows that Superleader has both positive and signifficant effect on work satisfaction, Superleader has positive effect but insignificant on work performance, and Job satisfaction has a positive and signifficant effect as well on work performance. While the indirect relationship between Superleader and Performance mediated by Job Satisfaction based on Sobel test shows significant effect
\end{abstract}

2018 FIA UB. All rights reserved.

\section{Introduction}

Changes in the business environment will have a change in business strategy. Changes to the business strategy will increasingly direct the leadership to clarify in what direction the vision and mission of the human resources sector will be brought. Human resources are the main asset of an organization, both business organizations and non-profit organizations. The future and sustainability of an organization depends on knowledge, skills and competencies as well as synergies between human resources as the driving force of the organization and supported by effective management of other resources within the organization. This is in accordance with Suprana's statement (2005) that the superiority of competitiveness is not determined by natural resources, technology, funds or anything but only by the only element of human resources, and the superiority of competitiveness is determined only by the quality of resources human power in managing and utilizing natural resources, technology and funds.

Given the importance of the role of human resources in the company in order to remain able to survive in a climate of free competition without limits, the role of human resources is no longer only the responsibility of employees, but is the responsibility of the leadership of the company. Human resource management, of course, must be carried out by professional leaders. Thus human resources can be interpreted as the management and utilization of resources that exist in individuals (employees). Management and utilization are maximally developed in the business world to achieve company goals. And individual development of employees who are companies.

Various field studies show that most of the organization's leaders are of the view that the moral idea or social responsibility associated with the activities of the organization they lead can be in line or may also conflict with their business interests. But in essence, modern organizations still need to work towards the harmonization of three principles, namely: rationality, efficiency and morality. The manager's technical skills and staffing skills are very important, but this is not enough, because leaders who have the ability and skills with routine work matters, may not necessarily motivate their employees to work better.

A leader now days is the same as a trainer or a coach. A great leader learn that role through training or coaching. Based on this phenomena, it is definitely 
needed to have a leader whose leadership can face both the challenges of the present time and the future. It is leadership that focuses on organization members to be able to make those members lead themselves. It is called Superleader. "Superleader is the one who leads others to lead themselves" (Manz and Sims, 1990). In a business organization - handling banking business - professional human force is absolutely important to be able to respond its customers' expectation through improving the organization performance. Rivai (2004) suggests a Superleader is a leader who leads others to lead themselves. This covers a set of attitudes which are intended to make subordinators possess their own attitudes and cognitive required to train self-leadership.

Mappaenre (2014) studied the relationship between Superleader and Performance. This research was conducted in some senior high schools in Makassar. The results showed that Superleader has a positive and significant effect on performance. It can be concluded that Superleader is totally important in improving subordinators work performance. Other studies also reveal that Superleader does not always have significant effect on subordinators work performance. Hadi (2011) conveys that superleader does not have significant effect on subordinators work performance. This means that the changes taking place in Superleader indicator will not affect the changes in the variable of subordinators work performance.

One important factor in human resource management in an organization is the creation of job satisfaction of employees/ employees. Job satisfaction according to Martoyo (1992) is basically a psychological aspect that reflects a person's feelings about his work. He will feel satisfied with the suitability between his abilities, skills and expectations with the work he faces. The existence of an increase in job satisfaction for employees certainly has an impact on the performance shown. Dessler in Handoko (2001) states that there are differences between employees who have job satisfaction and those who do not.

Employees who feel satisfaction in their work tend to have better records of attendance and compliance with regulations, but are less active in participating in trade union activities. These employees also usually have better performance than employees who do not have satisfaction in their work. Satisfaction is actually a subjective condition which is the result of a conclusion based on a comparison of what an employee receives from his work compared to what is expected, desired, and thought of as appropriate or entitled to it. While each employee/ employee subjectively determines how satisfying the work is. Robbins (2003) states the impact of job satisfaction on employee performance. Employees who feel satisfied with their work will have a greater chance of talking about positive things about their organization, helping others and going beyond estimates.

Thus employee job satisfaction has an important meaning for employees and companies in particular for the creation of positive conditions in the work environment. From the limitations regarding job satisfaction, it can be concluded simply that job satisfaction is a person's feeling towards his job. This means that the conception of job satisfaction sees it as a result of human interaction with the work environment. Besides that, someone's feeling of work is certainly a reflection of his attitude towards work. Miao (2011), Pushpakumari (2008), Edwards et al. (2008), and Christen et al. (2006) examined the relationship between job satisfaction and employee performance. From these studies found the results that job satisfaction has a positive and significant influence on employee performance. From this explanation it can be concluded that performance is also influenced by job satisfaction so companies also need to pay attention to the job satisfaction of their employees.

The findings of previous studies reveal the difference result among variables. The inconsistency among variables of those findings has been found and shown as the following:

a) There are differences on the finding related with the effect of superleader on employee work performance, and job satisfaction on employee work performance. Hadi's findings (2011) indicate that superleader has positive but not significant effect on work performance. whereas kalkavan's and Katrinli's findings (2014) show that there is no relationship between job satisfaction and work performance;

b) The novelty of this research is the absence of empirical support for the hypothesis which states the influence of Superleader (X1) on Job satisfaction (Y1); and

c) The number of research concerning superleader in developing countries in banking sectors particularly - is very limited.

This explanation indicates the research gap which is quite necessary to be studied for the sake of the development of human resource especially the ones concerning superleader, perceived organizational support, employee engagement, job satisfaction, and work performance as well.

To improve work performance of the executives in banking business now days, superleaders and perceived organizational support are needed. The ones who can create job satisfaction, employee engagement, and who are capable to increase work performance. Thus, this research is interesting to do since it examines the relationship model among Superleader and Job Satisfaction on Work Performance in Government Owned Bank Malang Regional Office based on the following considerations:

a) The phenomenon that occurs at this time is a strong commitment from stakeholders to the problem of poverty alleviation. For this reason, organizational management issues that are active in the financing sector are important things to get attention so that the optimization of human resource capabilities is needed to improve institutional performance; and

b) The magnitude of the role of a leader in fostering and triggering the creation of job satisfaction, the implementation of leadership in accordance with the characteristics of the Government Owned Bank Malang Regional Office is the main capital for the success of the organization which in turn can grow even improve employee performance. If subordinates 
are willing to change attitudes, the value of assumptions is such that they are in harmony with their organization, it is believed that they have a high level of trust in the integrity and credibility of their leaders.

The purpose to be achieved in this study is to analyze and explain the influence of Superleader on Job Satisfaction, analyze and explain the influence of Superleader on Employee Performance, analyze and explain the effect of Job Satisfaction on Employee performance.

\section{Theory}

\subsection{Superleader}

Superleader is the development of transformational leadership model. Power of a leader is shared with subordinators in order to make system and team function independently without supervision and control from a leader (Scarborough, 2001). Superleader is a leader who leads others to direct and lead themselves. Self-leadership designs and implements a system which allows and teaches members of organization to become a leader for himself. Indra (2016) states that a great leader must be able to lead himself in almost all aspects of himself. Self-leadership is the key to be able to lead others. It covers a set of strategies focusing on behaviour and ideas and concepts which can be used to mobilize oneself. In other words, self-leadership is everything people do to lead themselves (Mans and Sims, 1990).

Rivai (2004) suggests that superleaders are someone who leads others to lead themselves. Rivai statement is meant that superleader empowers subordinates/ employees to be able to become self leaders or become leaders for themselves. These approaches consist of the expansion of behavioral devices, all of which are intended to make followers have behavioral and cognitive abilities that are important for exercising selfleadership. Such leaders will be able to design and implement the system and teach employees to be selfleaders. Susanto (2009) equates Superleaders like conductors who lead an orchestra, he must ensure that the tone and sound are played harmoniously to produce beautiful music and tone. Furthermore Susanto (2009) stated that a superleader who is the one who leads other leaders under him.

\subsection{Kepuasan Kerja}

Martoyo (1992) says that job satisfaction basically is one psychological aspects that reflects someone's feeling toward his work; he will feel satisfied with the compatibility of his skill, competency and expectation with the works he faces. Satisfaction is actually a subjective psychological state which is deducted from a comparison on what employees receive from their work compared to what subjectively decides how his work satisfies him since the level of satisfaction varies among the employees.

Tiffin (1958), argues that job satisfaction is closely related to the attitude of employees towards their own work, work situation, cooperation between leaders and employees. Blum (1956) states that job satisfaction is a general attitude which is the result of some specific attitudes towards work factors, self-adjustment and individual social relations outside work. Jex (2002) defines job satisfaction as "the level of positive affection of a worker to work and work situation." Job satisfaction is always related to the attitude of the worker to his work. This attitude takes place in cognitive and behavioral aspects. Cognitive aspects of job satisfaction are workers' beliefs about work and work situations: That workers believe that their work is interesting, stimulating, boring or demanding. The aspect of work behavior is the tendency of workers' behavior towards their work which is shown through the work done, continues to stay in their position, or work regularly and discipline.

Davis and Newstrom (1985) describe "job satisfaction as a set of employees' feelings about the fun or not of their work". According to Robbins (2003) job satisfaction is "a general attitude towards someone's work that shows the difference between the number of awards received by workers and the amount they believe they should receive". Overall job satisfaction for an individual is the amount of job satisfaction (from every aspect of work) multiplied by the degree of importance of the job aspect for the individual. An individual will feel satisfied or dissatisfied with his job is something that is personal, that depends on how he perceives the suitability or conflict between his desires and the results (which he gets).

So, it can be concluded that the notion of job satisfaction is a positive attitude of the workforce which includes feelings and behavior towards their work through an assessment of one job as a sense of respect in achieving one of the important values of work.

\subsection{Employee Performance}

A company organization is established because it has certain goals that it wants and must achieve. In achieving its objectives every organization is influenced by its human resources. One of the most common activities done in an organization is employee performance, which is how someone does everything related to a job or role in the organization. Performance in carrying out its functions is not independent, but always relates to employee job satisfaction and the level of rewards given and influenced by individual skills, abilities and traits.

Performance is a reflection of the workaccomplishment level of a program or a policy in executing organizational vision and mission which have been put in well planned-strategies of the organization. Sedarmayanti (2011) conveys that performance means the output of an employee, a through managerial process in which that output must be able to be both proved and measures - compared to the establishes standards. Hasibuan (2002) says that performance is the output accomplished by an employee in conducting his jobs with his efforts, opportunities, and competency. According to Mathis and Jackson (2002) that employee performance is what influences how much they contribute to the organization, which includes output 
quantity, output quality, output period, attendance at work, and cooperative attitude.

\subsection{Hypothesis}

By considering the relationship between variables and the results of research in previous research, the research hypothesis is formulated as follows:

$\mathrm{H}_{1}$ : Superleader (X) has a significant effect on Job Satisfaction $\left(\mathrm{Y}_{1}\right)$

$\mathrm{H}_{2}$ : Superleaderhip (X) has a significant effect on Employee Performance $\left(\mathrm{Y}_{2}\right)$

$\mathrm{H}_{3}$ : Job Satisfaction $\left(\mathrm{Y}_{1}\right)$ has a significant effect on Employee Performance $\left(\mathrm{Y}_{2}\right)$

\section{Research Method}

This type of research is in accordance with the objectives and hypotheses is explanative research with a survey approach. Survey research is directed to illustrate the existence of a causal relationship between several situations described in the research model and on that basis a general conclusion is drawn. The unit of analysis in this study is individuals. The individual in question is an employee of the Government-Owned Bank of Malang Regional Office.

The population in this study were all employees of the Government-Owned Bank of Malang Regional Office, a number of 603 employees. Respondents in this study were supervisor-level employees, including Assistant, Assistant Managers, Managers, Assistant Vice Presidents, Vice Presidents, and Executive Vice Presidents. The selection of respondents who have equal positions with supervisors is intended because the information needed can be obtained from one particular target group that is able to provide the desired information because they do have such information and they meet the criteria determined by the researcher. Respondent data is divided into several regions with the following details:

Table 1 The Number of Supervisor - Level Officials and Above This Level in Malang District

\begin{tabular}{|c|c|c|}
\hline No & City & Amount \\
\hline 1 & Malang & 139 \\
\hline 2 & Madiun & 46 \\
\hline 3 & Kediri & 75 \\
\hline 4 & Probolinggo & 45 \\
\hline 5 & Banyuwangi & 39 \\
\hline 6 & Blitar & 43 \\
\hline 7 & Pasuruan & 45 \\
\hline 8 & Tulungagung & 39 \\
\hline 9 & Ponorogo & 47 \\
\hline 10 & Jember & 85 \\
\hline Total & & 603 \\
\hline
\end{tabular}

Source: Analytical result, 2017

Slovin Formula is applied to decide the number of sample as follows:

$$
n=\frac{N}{1+N e^{2}}
$$

$$
\begin{aligned}
& n=\frac{603}{1+603 \times 0.05^{2}} \\
& n=240,4786 \text { rounded to } 240 \text { people }
\end{aligned}
$$

Next, proportional sampling technique is used to get a proportional sample of each city which is in line with the number of supervisor - level officials and above. When the number of sample is identified, the number of each division is set proportionally by applying slovin method.

Table 2. The Number of Sample for Supervisor - Level Officials and Above in Malang District

\begin{tabular}{clrrr}
\hline No & \multicolumn{1}{c}{ Kota } & $\begin{array}{c}\text { Populasi } \\
\text { (orang) }\end{array}$ & Perhitungan & \multicolumn{1}{c}{ Hasil } \\
\hline 1 & Malang & 139 & $139 / 603 \times 240$ & $55,3=55$ \\
2 & Madiun & 46 & $46 / 603 \times 240$ & $18,3=18$ \\
3 & Kediri & 75 & $75 / 603 \times 240$ & $29,8=30$ \\
4 & Probolinggo & 45 & $45 / 603 \times 240$ & $17,9=18$ \\
5 & Banyuwangi & 39 & $39 / 603 \times 240$ & $15,5=15$ \\
6 & Blitar & 43 & $43 / 603 \times 240$ & $17,1=17$ \\
7 & Pasuruan & 45 & $45 / 603 \times 240$ & $17,9=18$ \\
8 & Tulungagung & 39 & $39 / 603 \times 240$ & 16 \\
9 & Ponorogo & 47 & $47 / 603 \times 240$ & $18,7=19$ \\
10 & Jember & 85 & $85 / 603 \times 240$ & $33,8=34$ \\
& & & &
\end{tabular}

Source: Analytical result, 2017

The type of data in this study can be grouped into two types, namely primary data and secondary data. Primary data: namely the data obtained directly from respondents related to the variables studied are collected from questions that can be filled by respondents who know the company's activities comprehensively related to the variables studied. For this purpose, the questionnaire will be filled by employees of the Government-Owned Bank of Malang Regional Office. Secondary data: namely documentary data obtained from the Government-Owned Bank database of the Malang Regional Office in the form of a description or company profile.

Analysis of the data used to prove the hypothesis proposed in this study uses Generalized Structured Component Analysis (GSCA). GSCA was developed by Heungsun Hwang, Hec Montreal, and Yhoshio Takene in 2004. The aim was to replace factors in linear combinations of indicators (manifest variables) in SEM analysis (Solimun, 2012). Tenehaus (2008) in Solimun (2012) said that GSCA is a new method of componentbased SEM, very important and can be used to calculate scores (not scale) and can also be applied to very small samples. This analysis approach uses the least square method in the parameter estimation process. In addition, GSCA can be used in structural models that involve variables with reflexive and / or formative indicators.

\section{Results and Discussion}

\subsection{Results}

The estimation results and the results of testing the hypothesis of the influence between variables in this study are as follows: 


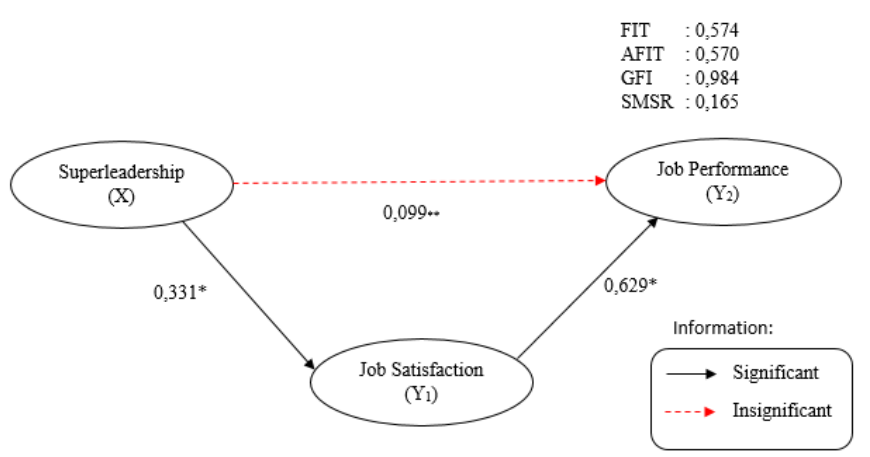

Figure 1. Path Diagram of Measurement Model and Structural Model

Source: Analytical result, 2017

Table 3. Recapitulation of Estimation Results and Hypothesis Testing

\begin{tabular}{cccccc}
\hline $\begin{array}{c}\text { Pengaruh antar Variabel } \\
\text { Variabel } \\
\text { independen }\end{array}$ & $\begin{array}{c}\text { Variabel } \\
\text { dependen }\end{array}$ & $\begin{array}{c}\text { Koefisien } \\
\text { Jalur }\end{array}$ & $\begin{array}{c}\text { Standard } \\
\text { Error }\end{array}$ & CR & Keterangan \\
\hline $\mathrm{X}$ & $\mathrm{Y}_{1}$ & 0.331 & 0.058 & $5.75^{*}$ & Signifikan \\
$\mathrm{X}_{1}$ & $\mathrm{Y}_{2}$ & 0.099 & 0.056 & 1.77 & Tidak signifikan \\
$\mathrm{Y}_{1}$ & $\mathrm{Y}_{2}$ & 0.629 & 0.072 & $8.79^{*}$ & Signifikan \\
& & & & & \\
\end{tabular}

Description:

$$
\begin{aligned}
& \mathrm{X}=\text { superleader; } \\
& \mathrm{Y}_{1} \quad \text { = job satisfaction; } \\
& \mathrm{Y}_{2} \quad=\text { respondent's performance; } \\
& * \quad=\mathrm{CR}>2
\end{aligned}
$$

\subsection{Discussion}

\subsubsection{Effect of Superleader on Job Satisfaction}

A business organization requires a leader who is capable and is willing to take an initiative to act proactively and take advantage of any business opportunity. A leader who can response new challenges. Besides, he is also the one who can take responsibility to face depressing business world with lots of uncertainties behind it. The future organizational leader must possess clear vision concerning what must be done professionally or personally. He must also the one who has a strong endurance to face setbacks even failures. A leader should be visionary and comprehends indeed where the organization will be navigated to. Leadership as a process of social influence determines the organizational goals, encourages positive habits of employees to reach the goal, and influences the sustainability of a business organization (Yukl, 1999).

A leader functioning both as a manager and a transformational leader is the main actor and the most decisive one to bring his organization to become a thriving business organization with its competitive advantage. The success of a leader mostly depends on his willingness to take ethical and moral responsibility motivation and behaviour of an organizational leader are essentially universal and prevalent in the world.

Superleader leadership is a leadership approach to lead oneself (Manz and Sims, 1990). Rivai (2004) conveys that a superleader is the one who leads others to be able to lead themselves. This approach covers an expansion of a set of behaviour devices intended to make subordinators possess attitudes and cognitive ability which are vital to train self-leadership.

The first hypothesis $\left(\mathrm{H}_{1}\right)$ conveys that superleader affects significantly on job satisfaction. The result indicates that path coefficient from superleader toward job satisfaction is 0.331 and $\mathrm{CR}=5.75$. This relationship has a positive and significant path coefficient (CR > 1.96). Thus, hypothesis H0 is denied and $\mathrm{Ha}$ is accepted. Superleader directly and significantly affects job satisfaction. Based on the result of that path coefficient, we can draw a conclusion that an increase in Superleader variable will increase job satisfaction of PT. Government-Owned Bank Malang Regional Office employees.

Superleader is considered to have positive effect on the job satisfaction of PT. Government-Owned Bank Malang Regional Office employees. Employees can feel satisfied with their job when there is a leader in the organization who trust them to be able to lead themselves. Then, they have room to develop their creativity and ideas. It can be concluded that having superleader in PT. Government-Owned Bank Malang Regional Office has a positive impact on job satisfaction of its employees.

This findings is a novelty explaining a relationship between superleader and job satisfaction. This study is expected to give theoretical contribution on the studies between superleader and job satisfaction.

\subsubsection{Effect of Superleader on Employee Performance}

Rivai (2004) states that a superleader is someone who leads others to lead themselves. This approach covers an expansion of a set of behavioural devices meant to make subordinators or followers possess an important behaviour and cognitive ability to train selfleadership. Applying this superleader is aiming at improving job or work performance of employees which is eliminating in improving organizational performance.

Path coefficient from superleader to employee performance is 0.099 and $\mathrm{CR}=1.77$. This relationship has path coefficient which is marked positive but insignificant $(\mathrm{CR}<1.96)$. Thus hypothesis nol $\left(\mathrm{h}_{0}\right)$ is accepted; superleader cannot explain directly explain employee performance. The third hypothesis of this research $\left(\mathrm{H}_{3}\right)$ which conveys that superleader affects employee performance is denied. This finding shows that the contribution of superleader in improving employee performance is not significant or significant. This takes place due to the fact that PT. GovernmentOwned Bank Malang Regional Office has already had a system which is run based on a fixed operating procedure standard. Employee performance, then, does not depend on and is not affected by leadership style applied by their leader. In addition, the result of the cross-tab between the recent position and the length of holding the recent position shows that most leaders hold their recent positions for one year which is considered a new category. This phenomena is due to the fact that in 2016 PT. Government-Owned Bank Malang Regional Office had a new regulation - East Java Province was split into 2 big areas. They are Surabaya Area and 
Malang Area offices. However, the role of Superleader cannot be ignored considering superleader has a vital effect on other variables related to employee performance. Further, Government-Owned Bank Malang Regional Office has implemented its own Value of Work Culture which covers Professionalism, Integrity, Customer - Oriented Service, and Continuous Improvement. Whereas, the primary core values developed by Government-Owned Bank Malang Regional Office are improving competency, providing the excellent output, being honest, being sincere, being disciplines, being consistent and responsible, providing a high quality of services through a synergistic partnership and continuously creative but innovative improvement. These factors drive to the fact that superleader does not give significant effect.

This finding is contrary to the finding of the study done by Mappaenre (2014) indicating that Superleader has a significant effect on performance. This takes place due to the different objects of the research where the system applied to each study is not the same.

\subsubsection{Effect of Job Satisfaction on Employee Performance}

Martoyo (1992) states that job satisfaction basically is one of a set of psychological aspects reflecting someone's feeling toward one's job or work. He will feel satisfied with the compatibility among competency, skill, and expectation with his job he faces.

Satisfaction, in fact, is subjective. It is a result of conclusion which is based on the comparison between what an employee receives from his job and what he expects, wants, and thinks as something worth having. Whereas every single employee subjectively decide how he is satisfied with his job.

From the explanation, it can be concluded that job satisfaction is someone's feeling toward his job. It means that the concept of job satisfaction views it as a result of human interaction with work environment. Furthermore, this feeling, at the same time, definitely constitutes a reflexion of one's attitude or behavior to his job. Fundamentally, job satisfaction is something which subjective to everyone. Every single individual has his own level of satisfaction that is different to each other depended on his value system. This condition is due to the fact that every individual is different from each other. The more aspects of jobs suitable to one's expectation, the higher his level of job satisfaction and vice versa. It can be concluded that job satisfaction felt by an employee has a positive effect on his job.

The path coefficient from job satisfaction to employee performance is 0.629 and $\mathrm{CR}=8.79$. This relationship has a positive and significant path coefficient (CR > 1.96). Thus hypothesis H0 is denied and $\mathrm{Ha}$ is accepted. Job satisfaction can directly explains employee performance. The third hypothesis of this study stating that job satisfaction affects employee performance is then accepted.

This finding indicates that employee expectation suits the reward they receive - even beyond it - to make them feel contented. The increase of job satisfaction level felt by employees leads to the growing level of employee performance at Government-Owned Bank Malang Regional Office. In this case, GovernmentOwned Bank Malang Regional Office should give special attention to its employees to improve its employees' job satisfaction in order to improve their performance. This finding backs up the study conducted by Ren - Tao Miao (2011) conveying that job satisfaction affects positively and significantly on employee performance.

\subsubsection{The Indirect Effect of Superleader (X) on Employee Performance $\left(Y_{3}\right)$ Through Job Satisfaction $\left(Y_{1}\right)$}

Based on the result of GSCA Test, we can see that the path coefficient (a) of superleader effect on job satisfaction $\left(\mathrm{Y}_{1}\right)$ is 0.331 with 0.058 as its standard error (Sa) While path coefficient (b) of job satisfaction effect $\left(\mathrm{Y}_{1}\right)$ on employee performance $\left(\mathrm{Y}_{2}\right)$ is 0.629 with 0.072 as its standard error (b). Inserting this value to the formula of Sobel Test, we obtain a value as big as 4.777 of statistic test. So, it can be concluded that the effect of superleader variable $(\mathrm{X})$ an employee performance $\left(\mathrm{Y}_{2}\right)$ is significantly mediated by job satisfaction $\left(\mathrm{Y}_{1}\right)$.

The finding indicates that the improving of someone's job satisfaction will lift up his job performance. The satisfaction one gets from his organization - among other things - is position. Employees view that someone with higher level of position will feel more satisfied with his job compared to the one having lower position. Besides, position has its own different levels. A job gives someone a position. When there is a pay raise, it will be considered as a raise in positions and the pride on this new position will alter employees' attitude and feeling. Employee job satisfaction can also be measured from Age stated that there is a relationship between job satisfaction and employee age. The relationship between employees and the leadership is very important in improving employee performance. Employee satisfaction can be through attention and good relationships from leaders to subordinates, so that employees will feel that they are an important part of the work organization (sense of belonging).

\begin{tabular}{|c|c|c|c|c|}
\hline Input: & & Test statistic: & Std. Error: & $p$-value \\
\hline a 0.331 & Sobel test: & 4.77779519 & 0.04357638 & 0.00000177 \\
\hline$b 0.629$ & Aroian test: & : 4.75600619 & 0.04377602 & 0.00000197 \\
\hline$s_{a} 0.058$ & Goodman test: & : 4.79988644 & 0.04337582 & 0.00000159 \\
\hline $\begin{array}{ll}s_{\mathrm{b}} & 0.072\end{array}$ & Reset all & & Calculate & \\
\hline
\end{tabular}

Figure 2. The Result of Computation of Indirect Effect among $\begin{array}{lll}\text { Variables } \mathrm{X}_{1} & \mathrm{Y}_{1} & \mathrm{Y}_{3}\end{array}$

\section{Conclusion}

a) Superleadership significantly and positively affects Job Satisfaction. The finding of this study is a novelty. It is expected that this finding gives a 
meaningful contribution both theoretically and practically;

b) Superleadership positively but insignificantly affects employee performance. The finding of this study does not back up the study conducted by Meppaenre and Ahmad (2014) indicating that superleadership significantly affects employee performance;

c) Job satisfaction positively and significantly affects employee performance. The finding of this study backs up the research done by Ramadhan and Sembiring (2014) showing that Job Satisfaction positively and significantly affects employee performance; and

d) Mediation of Job Satisfaction on the influence of Superleader variables on Employee Performance is significant.

\section{References}

Blum, Milton. L. (1956). Industrial Psychology and Its Social Foundation. New York Harper and Row, New York.

Christen, M., Iyer, G., \& Soberman, D. (2006). Job Satisfaction, Job Performance, and Effort: a Reexamination Using Agency Theory. Journal of Marketing, Vol. 70(1), pp.137-150.

Davis, Keith ., \& John W. Newstrom. (1985). Perilaku Dalam Organisasi. Jakarta: Erlangga.

Edwards, Bryan D, et al. (2008). Relationships between Facets of Job Satisfaction and Task and Contextual Performance. Applied Psychology, Vol. 57(3), pp.441-465.

Hadi, Dwi Prasetyo. (2011). Analisis Pengaruh Kepemimpinan Superleadership terhadap Kinerja dengan Komitmen sebagai Variabel Intervening. Aset, Vol. 13(2), pp.95-109.

Handoko, T. Hani. (2001). Manajemen Personalia dan Sumberdaya Manusia. PT. BPFE, Yogyakarta.

Hasibuan, Malayu (2002). Manajemen Sumber Daya Manusia: Pengertian Dasar, Pengertian, dan Masalah. PT. Toko Gunung Agung, Jakarta.

Jex, S.M. (2002). Organizational Psychology: A Scientist-Practitioner Approach. John Wiley \& Sons, New York.

Kalkavan, Selma., \& Katrinli, Alev. (2014). The Effects of Managerial Coaching Behaviors on the Employees' Perception of Job Satisfaction, Organisational Commitment, and Job Performance: Case Study on Insurance Industry in Turkey. Procedia - Social and Behavioral Sciences, Vol. 150, pp.1137-1147.

Manz C. Charles and Sims P, Henry, Jr. (1990). Superleadership: Leading Others To Lead Themselves. A Berkley Book, New York.

Mappaenre, Ahmad. (2014). Super Leadership Approach, Organizational Culture and Performance Satisfaction to Improve Teachers' Performance. International Research in Education, Vol. 2(1), pp.93-102.

Martoyo, Susilo. (1992). Manajemen Sumber Daya Manusia, Edisi Enam. CV. Haji Masagung, Jakarta.

Mathis, Robert. L., \& Jackson, John. H. (2002). Manajemen Sumber Daya Manusia, Edisi ke dua, Alih Bahasa oleh Jimmy Sadeli dan Bayu Prawira Hie. Salemba Empat, Jakarta.
Miao, R. (2011). Perceived Organizational Support, Job Satisfaction, Task Performance and Organizational Citizenship Behavior in China. Institute of Behavioral and Applied Management Journal, Vol.3(2), pp.531-563.

Pushpakumari, MD. (2008). The Impact of job satisfaction on job performance: An empirical analysis. (2008). City Forum, Vol. 9, Issue 1, pp. 89-105.

Ramadhan, Nabilah., and Jafar Sembiring. (2014). Pengaruh Employee Engagement terhadap Kinerja Karyawan di Human Capital Center PT. Telekomunikasi Indonesia, Tbk. Jurnal Manajemen Indonesia, Vol.14(1), pp. 47-58.

Rivai, Veithzal. (2004). Manajemen Sumber Daya Manusia untuk Perusahaan. Raja Grafindo Persada, Jakarta.

Robbins, Stephen P. (2003). Organizational Behavior. Pearson Education, New Jersey.

Scarborough, J. D. (2001). Transforming leadership In The Manufacturing Industry. J. Ind. Technol., Vol. 17(2), pp.1-13.

Sedarmayanti. (2011). Manajemen Sumber Daya Manusia, Reformasi Birokrasi dan Manajemen Pegawai Negeri Sipil (Cetakan Kelima). PT Refika Aditama, Bandung.

Solimun. (2012). Structural Equation Modelling (SEM) Lisrel dan Amos. Universitas Brawijaya, Malang.

Suprana. (2005). Naskah-naskah Kompas Jaya Suprana. Elex Media Komputindo, Jakarta.

Susanto, A. B. (2009). Super Leadership - Leading Others To Lead. PT Gramedia Pustaka Utama, Jakarta.

Tiffin, J., and Ernest J. M. (1958). Industrial Psychology. Prentice-Hall, Inc., Englewood Cliffs.

Yukl, Gary. (1999). An Evaluation Of Conceptual Weaknesses In Transformational And Charismatic Leadership Theories. Leadership Quarterly, Vol.10(2), pp.285-305. 